\title{
PENERAPAN MODEL PEMBELAJARAN PROBLEM BASED LEARNING UNTUK MENINGKATKAN SIKAP KERJA SAMA DAN HASIL BELAJAR SISWA PADA PEMBELAJARAN TEMATIK DI SDN KENCANA INDAH II
}

\author{
Ika Rahayu, M.Pd ${ }^{1}$ \\ Irna Yulistiani, S.Pd ${ }^{2}$ \\ Dosen STKIP Subang ${ }^{1}$ \\ Guru SDN 3 Namang ${ }^{2}$
}

\begin{abstract}
The problem of this research is to increase cooperation attitude and student learning outcomes through the implementation model of Problem Based Learning on thematic learning themes subthemes 11 wonderful togetherness nation of cultural diversity in the class IV SDN Kencana Indah 2 Rancaekek District of Bandung regency. This study aims to determine the attitude of cooperation and improvement of student learning outcomes through the implementation model of Problem Based Learning in Scene 1 Indahnya Mutual Subtheme 1 Nation Cultural Diversity in Class IV. As the subjects in this study is the fourth grade students of SDN Kencana Indah 2 as a single class of 33 students. The research object of this class action is the improvement of the attitude of cooperation and student learning outcomes at 1 beauty togetherness theme of cultural diversity subtema one nation by using model Problem Based Learning. Implementation of a class action (PTK) was done 2 cycles and each cycle is done with 2 meetings and at the end of each cycle of observation to determine the result of increased cooperation attitude and student learning outcomes. The results of the research can be argued that the percentage of category cooperative attitude of students the observation of the first cycle of the first meeting included the category "Not Visible" reached 57.7\%; category "Start Invisible" reached 72.7\%; category "Start Developing" reached 39.4\%; and the category "have been entrenched" reached $15.2 \%$, while in the second cycle in the category "Not Visible" reached 15.2\%; category "Start Invisible" reached 42.4\%; category "Start Developing" reached 33.3\%; and the category "have been entrenched" reached 93.9\%. Besides the increase occurred in student learning outcomes of the first cycle that $45.5 \%$ to $84.8 \%$ in the second cycle. Thus it can be argued conclusion that the application of the model of Problem Based Learning can improve the attitude of cooperation and student learning outcomes in thematic learning themes subthemes 11 wonderful togetherness nation of cultural diversity in the class IV SDN Kencana Indah 2 Rancaekek District of Bandung regency.

Keywords: Problem Based Learning Model Learning, an attitude of cooperation and student learning outcomes.
\end{abstract}

\section{ABSTRAK}

Permasalahan penelitian ini adalah peningkatan sikap kerja sama dan hasil belajar siswa melalui penerapan model Problem Based Learning pada pembelajaran tematik tema 1 indahnya kebersamaan subtema 1 keberagaman budaya bangsaku di kelas IV SDN Kencana Indah 2 Kecamatan Rancaekek 


\section{Didaktik : J urnal Pendidikan Guru Sekolah Dasar, ISSN : 2477-5673 Sekolah Tinggi Keguruan dan IImu Pendidikan Subang Volume I Nomor 2, J uli 2016}

Kabupaten Bandung. Penelitian ini bertujuan untuk mengetahui peningkatan sikap kerja sama dan hasil belajar siswa melalui penerapan model Problem Based Learning pada Tema 1 Indahnya Kebersamaan Subtema 1 Keberagaman Budaya Bangsaku di Kelas IV. Sebagai subjek dalam penelitian ini adalah siswa kelas IV SDN Kencana Indah 2 sebanyak satu kelas yang berjumlah 33 orang siswa. Objek penelitian tindakan kelas ini adalah peningkatan sikap kerja sama dan hasil belajar siswa pada tema 1 indahnya kebersamaan subtema 1 keberagaman budaya bangsaku dengan menggunakan model pembelajaran Problem Based Learning. Pelaksanaan tindakan kelas (PTK) dilakukan sebanyak 2 siklus dan masingmasing siklus dilakukan dengan 2 kali pertemuan dan pada setiap akhir siklus dilakukan observasi untuk mengetahui hasil peningkatan sikap kerja sama dan hasil belajar siswa. Hasil penelitian dapat dikemukakan bahwa kategori presentase sikap kerja sama siswa hasil observasi siklus I pertemuan I termasuk kategori "Belum Terlihat" mencapai 57,7\%; kategori "Mulai Terlihat" mencapai 72,7\%; kategori "Mulai Berkembang" mencapai 39,4\%; dan kategori "Sudah Membudaya" mencapai $15,2 \%$, sedangkan pada siklus II pada kategori "Belum Terlihat" mencapai 15,2\%; kategori "Mulai Terlihat" mencapai 42,4\%; kategori "Mulai Berkembang" mencapai 33,3\%; dan kategori "Sudah Membudaya" mencapai $93,9 \%$. Selain itu peningkatan terjadi pada hasil belajar siswa dari siklus I yaitu 45,5\% menjadi 84,8\% pada siklus II. Dengan demikian dapat dikemukakan kesimpulan bahwa penerapan model Problem Based Learning dapat meningkatkan sikap kerja sama dan hasil belajar siswa pada pembelajaran tematik tema 1 indahnya kebersamaan subtema 1 keberagaman budaya bangsaku di kelas IV SDN Kencana Indah 2 Kecamatan Rancaekek Kabupaten Bandung.

Kata Kunci : Model Pembelajaran Problem Based Learning, sikap kerja sama dan hasil belajar siswa.

\section{PENDAHULUAN}

Pendidikan adalah proses memproduksi sistem nilai dan budaya ke arah yang lebih baik antara lain dalam hal pembentukan kepribadian, keterampilan dan perkembangan intelektual peserta didik. Lembaga formal proses reproduksi sistem nilai dan budaya ini dilakukan terutama dengan mediasi proses belajar mengajar sejumlah mata pelajaran dalam kelas.

Peran pendidikan sangat penting untuk menciptakan masyarakat yang cerdas, damai, terbuka, demokratis, memiliki keterampilan poses, bersikap ilmiah, mampu memecahkan masalah dalam kehidupan sehari-hari, dan mencintai alam sekitar serta menyadari kebesaran dan keagungan Tuhan. Kemajuan bangsa Indonesia hanya dapat dicapai melalui penataan pendidikan yang baik. Upaya peningkatan mutu pendidikan diharapkan dapat menaikan harkat dan martabat manusia Indonesia. Untuk mencapai pembaharuan pendidikan di Indonesia perlu terus dilakukan untuk menciptakan dunia pendidikan yang adaptif terhadap perubahan jaman.

Hal ini sejalan dengan UndangUndang Sisdiknas No. 20 tahun 2003 yang berbunyi bahwa:

Pendidikan adalah usaha sadar dan terencana untuk mewujudkan suasana belajar dan proses pembelajaran agar peserta didik secara aktif mengembangkan potensi 


\section{Didaktik : J urnal Pendidikan Guru Sekolah Dasar, ISSN : 2477-5673 \\ Sekolah Tinggi Keguruan dan IImu Pendidikan Subang \\ Volume I Nomor 2, J uli 2016}

dirinya untuk memiliki kekuatan spiritual keagamaan, pengendalian diri, kepribadian, kecerdasan, akhlak mulia, serta keterampilan yang diperlukan dirinya, masyarakat bangsa dan Negara.

Sejalan dengan tujuan pendidikan dalam UU Pendidikan, Pendidikan Nasional berfungsi mengembangkan kemampuan dan membentuk watak serta peradaban bangsa yang bermartabat dalam rangka mencerdaskan kehidupan bangsa, bertujuan untuk berkembangnya potensi peserta didik agar menjadi manusia yang beriman dan bertaqwa kepada Tuhan Yang Maha Esa, berakhlak mulia, sehat, berilmu, cakap, kreatif, mandiri dan menjadi warga Negara yang demokratis serta bertanggung jawab.

Adapun upaya peningkatan mutu pendidikan melalui pembenahan dan penyempurnaan kurikulum yang diterapkan adalah kurikulum 2013 yaitu yang berbasis pembelajaran tematik. Pembelajaran tematik merupakan pendekatan pembelajaran yang mengintegrasikan berbagai kompetensi dari berbagai mata pelajaran ke dalam berbagai tema. Pengintegrasian tersebut dilakukan dalam berbagai hal, yaitu integrasi sikap, keterampilan dan pengetahuan dalam proses pembelajaran dan integrasi berbagai konsep dasar yang berkaitan. Tema merajut makna berbagai konsep dasar sehingga peserta didik tidak belajar konsep dasar secara parsial. Demikian pembelajarannya memberikan makna yang utuh kepada siswa seperti tercermin pada berbagai tema yang tersedia. Pembelajaran tematik integratif, tema yang dipilih harus berkenaan dengan alam dan kehidupan manusia. Berdasarkan sudut pandang psikologis, peserta didik belum mampu berpikir abstrak untuk memahami konten mata pelajaran yang terpisah.

Menurut (Rusman, 2012) pembelajaran tematik merupakan salah satu model pembelajaran terpadu (integrated instruction) yang merupakan suatu sistem pembelajaran yang memungkinkan siswa baik secara individual maupun kelompok aktif menggali dan menemukan konsep serta prinsipprinsip keilmuan secara holistik, bermakna dan autentik. Pembelajaran terpadu berorientasi pada praktik pembelajaran yang sesuai dengan kebutuhan dan perkembangan siswa.

Berdasarkan hal tersebut, seorang guru perlu menerapkan sebuah model yang mengarahkan siswa untuk berperan aktif dan menggali potensi yang ada pada dirinya sendiri, sehingga siswa mampu mengembangkan keterampilan-keterampilan tertentu seperti keterampilan dalam menyelesaikan masalah, keterampilan mengambil keputusan, keterampilan dalam menganalisis data, berpikir secara logis dan sistematis. Salah satu model pembelajaran yang melibatkan kemampuan kerja sama siswa untuk memecahkan masalah dalam pembelajaran serta untuk membangun konsep atau prinsip dengan kemampuannya sendiri yang mengintegrasikan keterampilan dan pengetahuan yang sudah dipahami sebelumnya yaitu bisa dengan menerapkan model Problem Based Learning (PBL). Model pembelajaran ini didasarkan pada beberapa teori belajar, antara lain teori kontruktivisme, teori belajar bermakna dari David Ausabel, teori belajar Vigotsky, dan teori belajar Jerome S. Bruner. 


\section{Didaktik : J urnal Pendidikan Guru Sekolah Dasar, ISSN : 2477-5673 \\ Sekolah Tinggi Keguruan dan IImu Pendidikan Subang \\ Volume I Nomor 2, J uli 2016}

\begin{abstract}
Menurut Moffit (Andi Prastowo, 2013) Pembelajaran Berbasis Masalah atau Problem Based Learning adalah suatu pendekatan pembelajaran yang menggunakan masalah dunia nyata sebagai suatu konteks bagi siswa untuk belajar tentang berpikir kritis dan keterampilan pemecahan masalah, serta untuk memperoleh pengetahuan dan konsep yang esensi dari materi pelajaran.
\end{abstract}

Pada model pembelajaran ini, siswa memahami konsep dan prinsip dari suatu materi yang dimulai dari bekerja dan belajar terhadap situasi atau masalah yang diberikan melalui investigasi, inquiry, dan pemecahan masalah. Siswa membangun konsep atau prinsip dengan kemampuannya sendiri yang mengintegrasikan keterampilan dan pengetahuan yang sudah dipahami sebelumnya.

Menurut Fogarty (Andi Prastowo, 2013), Problem Based Learning (PBL) dimulai dengan masalah yang tidak terstruktur (sesuatu yang kacau). Semua dari kekacauan ini siswa menggunakan berbagai kecerdasannya melalui diskusi dan penelitian untuk menentukan isu nyata yang ada.

Siswa harus dihadapkan pada hal-hal yang nyata yang terjadi di lingkungan sekitar siswa sehingga dapat belajar secara konkrit bukan hanya melalui konsep-konsep saja. Upaya meningkatkan kerja sama dan hasil belajar siswa dalam pembelajaran diperlukan strategi model pembelajaran yang efektif dengan menyajikan seperangkat fakta yang terjadi di lingkungan sekitar, siswa harus melakukan sesuatu, mengetahui dan memecahkan masalah yang berkaitan dengan masalah-masalah yang dialamimnya. Berkaitan dengan hal ini, maka bisa menerapkan pembelajaran melalui model Problem Based Learning (PBL).

Atas dasar latar belakang masalah sebagaimana telah diutarakan di atas, maka saya memandang penting dan perlu untuk melakukan penelitian dengan judul "Penerapan Model Problem Based Learning untuk Meningkatkan Kerja Sama dan Hasil Belajar Siswa pada Pembelajaran Tematik" (Penelitian Tindakan Kelas pada Tema Indahnya Kebersamaan Subtema Keberagaman Budaya Bangsaku di Kelas IV SDN Kencana Indah 2 Kecamatan Rancaekek Kabupaten Bandung)

\section{DASAR PEMIKIRAN}

\section{Pembelajaran Tematik}

Pembelajaran tematik adalah model pembelajaran terpadu yang menggunakan pendekatan tematik dengan melibatkan beberapa mata pelajaran untuk memberikan pengalaman bermakna kepada siswa.

Disebut "bermakna" menurut (Rusman, 2013) dikarenakan dalam pembelajaran tematik siswa akan memahami konsep-konsep yang mereka pelajari melalui pengalaman langsung dan menghubungkannya dengan konsep lain yang telah dipahaminya.

Dengan menggunakan istilah lain yang tidak jauh berbeda, Mamat S.B. dkk, (Andi Prastowo, 2013) memaknai pembelajaran tematik sebagai pembelajaran terpadu, dengan mengelola pembelajaran yang mengintegrasikan materi dari beberapa mata pelajaran dalam topik pembicaraan yang disebut tema. Pembelajaran tematik merupakan proses pembelajaran yang penuh makna dan berwawasan multikurikulum, yaitu pembelajran yang berwawasan penguasaan dua 


\section{Didaktik : J urnal Pendidikan Guru Sekolah Dasar, ISSN : 2477-5673 Sekolah Tinggi Keguruan dan Ilmu Pendidikan Subang Volume I Nomor 2, J uli 2016}

hal pokok terdiri dari penguasaan bahan (materi) ajar yang lebih bermakna bagi kehidupan siswa serta pengembangan kemampuan berpikir matang dan bersikap dewasa agar dapat mandiri dalam memecahkan masalah kehidupan.

Pada praktiknya, pendekatan pembelajaran tematik ini bertolak dari suatu tema yang dipilih dan dikembangkan oleh guru bersama siswa dengan memperhatikan keterkaitannya dengan isi mata pelajaran. Tema adalah pokok pikiran atau gagasan pokok yang menjadi pokok pembicaraan. Tujuan dari adanya tema ini bukan hanya untuk menguasai konsep-konsep dalam suatu mata pelajaran, akan tetapi juga dalam keterkaitannya denngan konsep dari mata pelajaran.

Lebih lanjut, perlu dipahami pula bahwa pembelajaran tematik merupakan pembelajaran terpadu yang menekankan keterlibatan siswa dalam pembelajaran. Siswa aktif terlibat dalam proses pembelajaran dan pemberdayaan dalam memecahkan masalah, sehingga hal ini menumbuhkan kreativitas sesuai dengan potensi dan kecenderungan mereka yang berbeda satu dengan lainnya. Sekaligus, dengan diterapkannya pembelajaran tematik, siswa diharapkan dapat belajar dan bermain dengan kretaivitas yang tinggi. Sebab, dalam pembelajaran tematik, belajar tidak semata-mata mendorong siswa untuk mengetahui (learning to know), tetapi belajar juga untuk melakukan (learning to do), untuk menjadi (learning to be), dan untuk hidup bersama (learning to live together). Model pembelajaran ini juga lebih mengutamakan kegiatan pembelajaran siswa, yaitu melalui belajar yang menyenangkan (Joyful learning) tanpa tekanan dan ketakutan, tetapi tetap bermakna bagi siswa.

Telah dijelaskan bahwa pembelajaran tematik merupakan salah satu model dari pembelajaran terpadu. Pembelajaran terpadu pada dasarnya terkait erat dengan keberadaan pola pendekatan kurikulum yang terpadu (integrated curriculum approach).

Berdasarkan beberapa definisi tersebut, pada dasarnya semuanya mendukung bahwa kurikulum terpadu merupakan pendekatan edukasional yang mempersiapkan siswa untuk menghadapi pembelajaran seumur hidup (long live education).

Sementara itu, konsep pembelajaran terpadu sendiri pada dasarnya telah lama dikemukakan oleh Jhon Dewey sebagai upaya untuk mengintegrasikan perkembangan dan pertumbuhan siswa serta kemampuan pengetahuannya. la memberikan pengertian bahwa pembelajaran terpadu adalah pendekatan untuk mengembangkan pengetahuan siswa dalam pembentukan pengetahuan berdasarkan pada interaksi dengan lingkungan dan pengalaman kehidupannya. Hal ini membantu siswa untuk belajar menghubungkan hal yang telah dan sedang dipelajari. Dengan kata lain, model pembelajaran terpadu merupakan suatu sistem pembelajaran yang memungkinkan siswa secara individual ataupun kelompok aktif mencari, menggali, dan menemukan konsep serta prinsip keilmuan secara holistik, bermakna, dan autentik.

Pembelajaran terpadu akan terjadi apabila peristiwa-peristiwa autentik atau ekspolari topik atau tema menjadi pengendai di dalam kegiatan pembelajaran. Dengan berpartisipasi di dalam eksplorasi tema atau peristiwa tersebut, siswa 


\section{Didaktik : J urnal Pendidikan Guru Sekolah Dasar, ISSN : 2477-5673 Sekolah Tinggi Keguruan dan IImu Pendidikan Subang Volume I Nomor 2, J uli 2016}

mampu belajar proses dan isi beberapa mata pelajaran secara serempak. Secara umum, pola pengintegrasian materi atau tema pada model pembelajaran terpadu tersebut dapat dikelompokkan menjadi tiga klasifikasi pengintegrasian kurikulum, yaitu pengintegrasian di dalam satu disiplin ilmu, beberapa disiplin ilmu, serta di dalam dan beberapa disiplin ilmu.

Berdasarkan penjelasan tersebut dapat ditarik kesimpulan bahwa pembelajaran tematik merupakan salah satu jenis pembelajaran terpadu, dimana kurikulum terpadu adalah induknya. Dengan kata lain, keberadaan model pembelajaran tematik terkait erat dengan keberadaan model pembelajarn terpadu, dan secara langsung maupun tidak langsung terkait erat dengan keberadaan kurikulum terpadu.

\section{Problem Based Learning}

Menurut (Winataputra, 2010) kegiatan belajar melalui pemecahan masalah bermanfaat untuk mengembangkan kemampuan peserta didik dalam mengidentifikasi, mengembangkan kemampuan berfikir alternative, dan kemampuan mengambil keputusan berdasarkan alternative yang tersedia.

Dari konsep yang telah dikemukakan Suherman menjelaskan bahwa model pembelajaran adalah suatu bentuk bagaimana interaksi yang tercipta antara guru dan siswa berhubungan dengan strategi, pendekatan, metode dan teknik pembelajaran yang digunakan dalam proses pembelajaran. Belajar terjadi dari aksi siswa, dan pendidik yang berperan dalam memfasilitasi terjadinya aktivitas kontruksi pengetahuan oleh pembelajar.
Pendidik harus memusatkan perhatiannya untuk membantu peserta didik dalam mencapai keterampilan self directed learning (pembelajaran yang berpusat pada siswa).

Pengertian Problem Based Learning menurut Kolmos (Sigit, 2013) dinyatakan sebagai:

"Problem Based Learning is an instructional method that challenges students to "learn to learn," working cooperativelly in groups to seek solutions to real world problem" (Kolmos etal,. 2007)

Dari pernyataan Kolmos diatas diketahui bahwa Problem Based Learning merupakan metode pembelajaran yang didalamnya terdapat tantangan kepada siswa untuk menemukan solusi sebagai wujud dari proses belajar.

Joyce \& Weil (Rusman, 2012) berpendapat bahwa model pembelajaran adalah suatu rencana atau pola yang dapat digunakan untuk membentuk kurikulum (rencana pembelajaran jangka panjang), merancang bahan-bahan pembelajaran di stau kelas atau lain. Model pembelajaran ini dapat dijadikan pola pilihan, artinya para guru boleh memilih model pembelajaran yang sesuai dan efisien untuk mencapai tujuan pembelajaran tersebut.

Hung et al. (sigit, 2013) mengemukakan pendapat tentang Problem Based Leraning sebagai berikut :

"Problem Based Learning is an instructional method that initiates students' learning by creating a need to solve an authentic problem. During the problem-solving process, student contruct content knowledge and develop problem-solving skill as well 


\section{Didaktik : J urnal Pendidikan Guru Sekolah Dasar, ISSN : 2477-5673 \\ Sekolah Tinggi Keguruan dan IImu Pendidikan Subang Volume I Nomor 2, J uli 2016}

as self-directed learning skills while working toward a solusion to the problem"

Artinya bahwa Problem Based Learning adalah metode pembelajaran yang menuntut siswa untuk menemukan solusi dari suatu permasalahan yang dihadapi dengan memahami kebutuhan-kebutuhan mendasar sebagai bekal menyelesaikan masalah yang ada. Siswa dihadapkan kepada permasalahan sebagai langkah untuk memberikan rangsangan agar tejadi kegiatan belajar. Dengan permasalahan yang dihadapi oleh siswa diharapkan mampu melakukan langkah-langkah yang tepat dalam menyelesaikan masalah tersebut.

Menurut (Nurhadi ,2004) Pembelajaran Berbasis Masalah (Problem Based Learning) adalah suatu model pembelajaran yang menggunakan masalah dunia nyata sebagai konteks bagi siswa untuk belajar tentang cara berpikir kritis dan keterampilan pemecahan masalah, serta untuk memperoleh pengetahuaan dan konsep yang esensial dari materi pelajaran.

Sedangkan menuruut Moffit (Depdiknas, 2002) mengemukakan bahwa Pembelajaran Berbasis Masalah merupakan suatu pendekatan pembelajaran yang menggunakan masalah dunia nyata sebagai suatu konteks bagi siswa untuk belajar tentang berpikir kritis dan keterampilan pemecahan masalah serta untuk memperoleh pengetahuan dan konsep yang esensi dari materi pelajaran.

Dari semua pendapat diatas maka dapat ditarik kesimpulan bahwa pembelajaran Berbasis Masalah (Problem Based Learning) adalah suatu proses belajar dengan mengeluarkan kemampuan siswa dengan betul-betul dioptimalisasikan melalui proses kerja kelompok atau tim yang sistematis, sehingga siswa dapat memberdayakan, mengasah,menguji dan mengembangkan kemampuan berfikirnya secara berkesinambungan yang berorientasi pada masalah dunia nyata. Karena perkembangan intelektual siswa terjadi pada saat individu berhadapan dengan pengalaman baru dan menantang serta ketika mereka berusaha memecahkan masalah yang dimunculkan.

\section{Hasil Belajar}

Menurut Ernest R. Hilgard dalam (Sumardi Suryabrata, 1984) belajar merupakan proses perbuatan yang dilakukan dengan sengaja, yang kemudian menimbulkan perubahan, yang keadaannya berbeda dari perubahan yang ditimbulkan oleh lainnya.

Hasil belajar diartikan sebagai tingkat keberhasilan siswa dalam memepelajari materi sekolah yang dinyatakan dengan nilai yang diperoleh dari hasil tes mengenai sejumlah materi pelajaran tertentu. Menurut Anni (Euis Nina, 2009) hasil belajar adalah perubahan yang diperoleh pembelajaran setelah mengalami aktivitas belajar.

Kegiatan belajar mengajar berupaya untuk mengetahui tingkat keberhasilan (pemahaman) siswa dalam mencapai tujuan yang diterapkan, maka evaluasi hasil belajar memiliki saran berupa ranah kognitif, afektif, dan psikomotorik.

Ranah afektif berkenaan dengan sikap yang terdiri dari lima aspek yaitu penerimaan, jawaban, penilaian, organisasi, dan interaksi. Sedangkan ranah psikomotorik berkenaan dengan hasil belajar keterampilan dan kemampuan perseptual, 


\section{Didaktik : J urnal Pendidikan Guru Sekolah Dasar, ISSN : 2477-5673 \\ Sekolah Tinggi Keguruan dan Ilmu Pendidikan Subang \\ Volume I Nomor 2, J uli 2016}

keharmmonisan (ketepatan), gerakan keterampilan kompleks, gerakan ekspresif dan interpretatif.

\section{METODE PENELITIAN}

Desain penelitian ini menggunakan model penelitian tindakan kelas yang terdiri dari 2 siklus. Setiap siklusnya meliputi tahapan perencanaan, pelaksanaan tindakan, observasi dan refleksi.

\section{HASIL PENELITIAN}

Berdasarkan kegiatan pelaksanaan siklus I persentase hasil pretest siswa yang mengalami ketuntasan belajar sebelum menggunakan model Problem Based Learning sebesar 33,3\% dan persentase siswa yang tuntas pada postest siklus I setelah menggunakan model Problem Based Learning sebesar 45,5\%. Ini membuktikan bahwa uji hasil belajar siswa mengalami peningkatan sehingga jumlah siswa yang tuntas setelah menggunakan model Problem Based Learing berdasarkan grafik menjadi naik. Siswa yang tidak tuntas pada saat pretest siklus I sebelum menggunakan model Problem Based Learning memiliki persentase $66,7 \%$, sedangkan pada saat diadakan postest siklus I dengan menggunakan model Problem Based Learning mengalami penurunan dengan jumlah persentase sebesar $\mathbf{5 4 , 5 \%}$. Berdasarkan hasil akhir belajar (postest) siswa yang tuntas masih jauh mencapai kriteria ketuntasan belajar yang ditetapkan, oleh karena itu perlu dilakukan penelitian selanjutnya. Hal ini dapat dilihat dari gambar 1 dibawah ini.

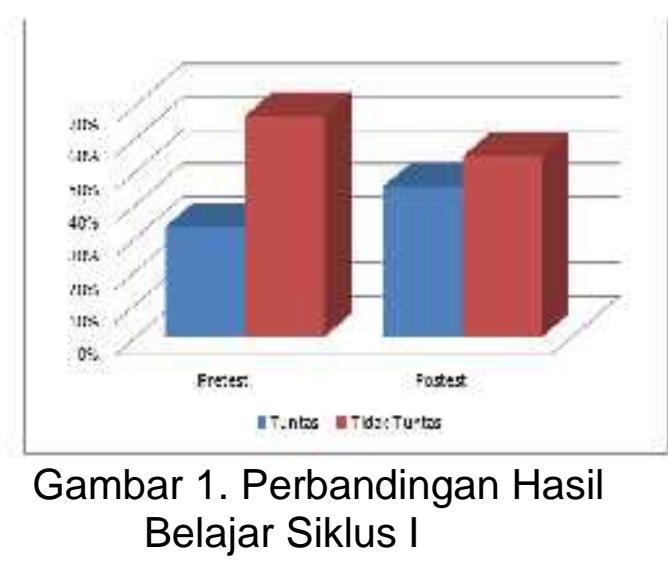

Untuk sikap kerja sama siswa, rata-rata sikap kerja sama 2,1 yaitu siswa masih ada yang belum sepenuhnya terlaksana sesuai aspek yang telah ditentukan. Berdasarkan data di atas pada kategori "Belum Terlihat" mencapai 57,7\%; kategori "Mulai Terlihat" mencapai 72,7\%; kategori "Mulai Berkembang" mencapai 39,4\%; dan kategori "Sudah Membudaya" mencapai $15,2 \%$. Jadi, sikap kerja sama siswa masih rendah dan perlu ditingkatkan lagi.

Sedangkan untuk respon siswa terhadap pembelajaran yang diterapkan, dari hasil angket diketahui persentase siswa memilih "ya" sebanyak $74,5 \%$ dan memilih "tidak" sebanyak $25,5 \%$. Kesimpulan dari jumlah persentase yang diperoleh menyatakan bahwa pernyataan atau respon siswa positif "ya" apabila pembelajaran menggunakan model Problem Based Learing pada pembelajaran tematik dapat meningkatkan sikap kerja sama dan hasil belajar siswa.

Pada siklus II, persentase hasil pretest siswa yang mengalami ketuntasan belajar sebelum menggunakan model Problem Based Learning sebesar $60,6 \%$ dan persentase siswa yang tuntas pada postest siklus II setelah menggunakan model Problem Based 


\section{Didaktik : J urnal Pendidikan Guru Sekolah Dasar, ISSN : 2477-5673 Sekolah Tinggi Keguruan dan Ilmu Pendidikan Subang Volume I Nomor 2, J uli 2016}

Learning sebesar $\mathbf{8 4 , 8 \%}$. Uji hasil belajar siswa ini mengalami peningkatan dapat dilihat pada jumlah siswa yang tuntas setelah menggunakan model Problem Based Learning berdasarkan grafik menjadi naik. Hal ini membuktikan bahwa adanya peningkatan ketuntasan hasil belajar dari siklus I, persentase $\mathbf{8 4 , 8 \%}$ hasil akhir belajar siswa pada siklus II ini telah mencapai kriteria ketuntasan belajar yang ditetapkan yaitu $80 \%$. Peneliti memberhentikan tindakan karena hasil akhir telah mencapai kriteria ketuntasan.

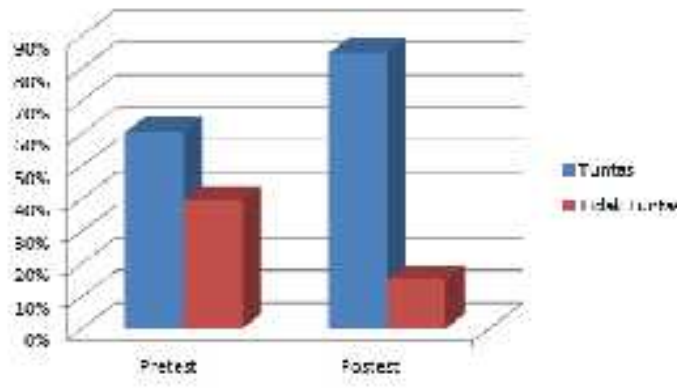

Gambar 2. Perbandingan Hasil Belajar Siklus II

Untuk jumlah presentase aspek perilaku sikap kerja sama siswa selama aktivitas pembelajaran pada kategori "Belum Terlihat" mencapai 15,2\%; kategori "Mulai Terlihat" mencapai 42,4\%; kategori "Mulai Berkembang" mencapai 33,3\%; dan kategori "Sudah Membudaya" mencapai 93,9\%. Hal ini membuktikan bahwa dengan menggunakan model Problem Based Learning sikap kerja sama siswa mengalami peningkatan, tetapi masih ada aspek yang belum sepenuhnya terlaksana dengan baik.

Sedangkan untuk respon siswa terhadap pembelajaran,dari hasil angket yang diperoleh menunjukan bahwa dari 33 orang siswa dari 10 pertanyaan yang disediakan, maka diperoleh persentase siswa memilih "ya" sebanyak $91,5 \%$ dan memilih “tidak" sebanyak 8,5\%. Jumlah persentase yang diperoleh dapat disimpulkan bahwa respon siswa terhadap pembelajaran menggunakan model Problem Based Learning dapat meningkatkan sikap kerja sama dan dapat mengecek pemahaman belajar siswa.

\section{PEMBAHASAN}

Berdasarkan hasil belajar dari pretest yang diberikan guru sebelum menggunakan model Problem Based Learning pada siswa kelas IV SDN Kencana Indah 2 tahun ajaran 2014/2015 menunjukkan bahwa sikap kerja sama dan hasil belajar siswa terhadap materi mengenai tema indahnya keberagaman subtema keberagaman budaya bangsaku pada pembelajaran 4 dan 5 sebelum tindakan masih sangat rendah. Hal ini dapat dilihat dari hasil ketuntasan belajar pretest yang diberikan sebelum menggunakan model Problem Based Learning pada siklus I yaitu hanya 11 orang atau $33,3 \%$ dari 33 orang siswa yang mencapai nilai di atas KKM, siklus II jumlah siswa yang hadir 33 orang yang mengalami ketuntasan belajar sebanyak 20 orang atau $60,6 \%$.

Meningkatkan ketuntasan belajar siswa yang optimal terhadap pelajaran perlu dilakukan proses belajar yang lebih baik dengan memperhatikan perkembangan anak didik dan sarana penunjang, salah satu upaya tersebut adalah dengan mengoptimalkan pembelajaran kerja kelompok atau tim yang sistematis, sehingga siswa dapat memberdaya, mengasah, menguji dan mengembangkan kemampuan berpikirnya secara berkesinambungan yang berorientasi pada masalah dunia nyata.

Menurut (Winaputra, 2010) kegiatan belajar melalui pemecahan 


\section{Didaktik : J urnal Pendidikan Guru Sekolah Dasar, ISSN : 2477-5673 \\ Sekolah Tinggi Keguruan dan IImu Pendidikan Subang \\ Volume I Nomor 2, J uli 2016}

masalah bermanfaat untuk mengembangkan kemampuan peserta didik dalam mengidentifikasi, mengembangkan kemampuan berpikir alternativ, dan kemampuan mengambil keputusan berdasarkan alternativ yang tersedia.

Berdasarkan hasil angket yang dibagikan kepada setiap siswa kelas IV SDN Kencana Indah 2 terhadap pembelajaran tematik dengan menggunakan model Problem Based Learning pada siklus I dari jumlah 33 siswa dengan 10 pernyataan diperoleh persentase jawaban siswa yang memilih "ya" sebanyak $\mathbf{7 4 , 5} \%$ dan memilih "tidak" sebanyak $25,5 \%$. Pada siklus II dari jumlah 33 siswa dengan 10 pernyataan diperoleh persentase jawaban siswa yang memilih "ya" sebanyak $\mathbf{9 1 , 5 \%}$ dan memilih "tidak" sebanyak $\mathbf{8 , 5 \%}$.

Menurut (Nurhadi, 2004) Pembelajaran Berbasis Masalah (Problem Based Learning) adalah suatu model pembelajaran yang menggunakan masalah dunia nyata sebagai konteks bagi siswa untuk belajar tentang cara berpikir kritis dan keterampilan pemecahan masalah, serta untuk memperoleh pengetahuaan dan konsep yang esensial dari materi pelajaran.

Sedangkan menuruut Moffit (Depdiknas, 2002) mengemukakan bahwa Pembelajaran Berbasis Masalah merupakan suatu pendekatan pembelajaran yang menggunakan masalah dunia nyata sebagai suatu konteks bagi siswa untuk belajar tentang berpikir kritis dan keterampilan pemecahan masalah serta untuk memperoleh pengetahuan dan konsep yang esensi dari materi pelajaran.

Berdasarkan data tersebut dapat disimpulkan bahwa hampir semua siswa memberikan respon pernyataaan "ya" dalam pembelajaran untuk meningkatkan sikap kerja sama dan hasil belajar siswa. Hal tersebut disebabkan karena proses pembelajaran menyenangkan dengan menggunakan model Problem Based Learning.

Berdasarkan hasil observasi terhadap aktivitas belajar siswa kelas IV SDN Kencana Indah 2 setelah dilakukan pada tindakan siklus I dan siklus II yang mengalami peningkatan. Aktivitas pemahaman siswa yang tampak yaitu tingkah laku siswa selama proses pembelajaran yang meliputi pola belajar kelompok, aktif dalam kelompok, berdiskusi, tanya jawab, mendeskripsikan, menjawab pertanyaan guru, menyelesaikan masalah dalam LKS, menyimpulkan hasil diskusi dan mempersentasikan hasil kerja kelompok.

Pada diskusi kelompok dengan bimbingan guru menggunakan model Problem Based Learning, siswa terlihat menjadi lebih aktif baik dalam bekerja sama memecahkan masalah dan dalam mengeluarkan pendapatnya. Hal tersebut dapat dilihat dari hasil penilaian pengamatan aktivitas siswa pada lembar observasi yang dilakukan oleh observer yaitu pada observasi siklus I menilai sikap kerja sama siswa dalam proses pembelajaran yang termasuk kategori "Belum Terlihat" mencapai 57,7\%; kategori "Mulai Terlihat" mencapai 72,7\%; kategori "Mulai Berkembang" mencapai 39,4\%; dan kategori "Sudah Membudaya" mencapai $15,2 \%$, aspek yang belum terlaksana pada siklus I disebabkan oleh belum terbiasanya siswa dengan pola belajar kelompok sehingga dilakukan penjelasan kepada siswa untuk menyelesaikan tugas bersama kelompoknya. Penilaian observer terhadap aktivitas siswa selama 


\section{Didaktik : J urnal Pendidikan Guru Sekolah Dasar, ISSN : 2477-5673 \\ Sekolah Tinggi Keguruan dan IImu Pendidikan Subang \\ Volume I Nomor 2, J uli 2016}

siklus II yang termasuk kategori "Belum Terlihat" mencapai 15,2\%; kategori "Mulai Terlihat" mencapai 42,4\%; kategori "Mulai Berkembang" mencapai 33,3\%; dan kategori "Sudah Membudaya" mencapai $93,9 \%$, peningkatan pada siklus II ini disebabkan oleh siswa yang sudah mulai terbiasa dengan pola belajar kelompok, siswa yang aktif dan bekerja sama dalam kelompoknya.

Berdasarkan nilai hasil belajar siswa kelas IV SDN Kencana Indah 2 pada siklus I hasil belajar siswa yang mengalami ketuntasan belajar berjumlah 15 orang atau 45,5\%, sedangkan siswa yang tidak tuntas nilainya di bawah KKM sebanyak 18 orang atau $54,5 \%$ dari 33 orang siswa. Pada siklus II jumlah siswa yang tuntas nilainya di atas KKM sebanyak 28 orang atau $84,8 \%$, sedangkan siswa yang tidak tuntas nilainya $\leq \mathrm{KKM}$ sebanyak 5 orang atau $15,2 \%$ dari 33 orang siswa.

Berdasarkan peningkatan belajar dari setiap siklus tersebut, maka pembelajaran dengan menggunakan model Problem Based Learning pada pembelajaran tematik dapat meningkatkan sikap kerja sama dan hasil belajar siswa pada tema indahnya kebersamaan sub tema keberagaman budaya bangsaku dan pembelajaran 4 dan 5 di kelas IV SDN Kencana Indah 2 tahun ajaran 2014/2015.

Menurut Reigeluth (Rusmono, 2012), terdapat tiga hal dalam pembelajaran yaitu: "Kondisi pembelajaran yang mementingkan perhatian pada karakteristik pelajaran, siswa, tujuan dan hambatannya, serta apa saja yang perlu diatasi oleh guru. Selain itu guru juga perlu memperhatikan pengelolaan pembelajaran dan pengelolaan kelas".
Sedangkan menuruut Moffit (Depdiknas, 2002) mengemukakan bahwa Pembelajaran Berbasis Masalah merupakan suatu pendekatan pembelajaran yang menggunakan masalah dunia nyata sebagai suatu konteks bagi siswa untuk belajar tentang berpikir kritis dan keterampilan pemecahan masalah serta untuk memperoleh pengetahuan dan konsep yang esensi dari materi pelajaran.

Berdasarkan asumsi tersebut model Problem Based Learning cocok diterapkan untuk pola interaksi dan meningkatkan sikap kerja sama dan hasil belajar siswa pada tema indahnya kebersamaan subtema keberagaman budaya bangsaku pembelajaran 4 dan 5 di kelas IV SDN Kencana Indah 2.

Hal ini dapat diketahui bahwa pada siklus I hasil belajar siswa SDN Lebaksiuh jumlah siswa yang tuntas sebanyak 11 orang dengan persentase ketuntasan 19,44 \%. Hasil belajar siswa SDN Lebaksiuh pada siklus II jumlah siswa yang tuntas sebanyak 32 orang dengan persentase ketuntasan $72,34 \%$ dan pada siklus III jumlah siswa yang tuntas sebanyak 40 siswa dengan persentase ketuntasan 85,63\%. Berdasarkan data di atas dengan ketetapan KKM 70 dan presentase keberhasilan 75\%. Septian Apendi menarik kesimpulan, bahwa denagn penerapan Model Problem Based Learning dapat meningkatkan hasil belajar dan pemahaman siswa dalam pembelajaran IPS. Pada siklus III siswa sudah mampu memahami materi makhluk hidup dilingkungannya. Siklus pun dihentikan dan dinyatakan berhasil. Meningkatnya hasil belajar tersebut di pengaruhi oleh sikap kerja sama siswa agar mudah memahami konsep yang diajarkan dengan model 


\section{Didaktik : J urnal Pendidikan Guru Sekolah Dasar, ISSN : 2477-5673 \\ Sekolah Tinggi Keguruan dan IImu Pendidikan Subang Volume I Nomor 2, J uli 2016}

Problem Based Learning, selain itu juga untuk meningkatkan kualitas pembelajaran tematik.

Teori yang dikemukakan pada tinjauan pustaka dan penelitian sebelumnya menunjukkan bahwa penggunaan model Problem Based Learning sangat mempengaruhi sikap kerja sama siswa yang berdampak pada hasil belajar siswa. Penggunaan model Problem Based Learning ini dalam proses pembelajaran merupakan suatu teknik yang baik dalam merangsang siswa untuk lebih aktif dan berfikir kritis karena siswa diberikan kesempatan untuk mencari sendiri pemecahan masalah dengan kerjasama kelompok sehingga mereka lebih mudah memahami materi.

Jadi, dapat disimpulkan bahwa dengan menggunakan model Problem Based Learning dapat meningkatkan sikap kerja sama dan hasil belajar siswa pada tema indahnya kebersamaan subtema keberagaman budaya bangsaku pembelajaran 4 dan 5 di kelas IV SDN Kencana Indah 2.

\section{KESIMPULAN}

Berdasarkan hasil penelitian tindakan kelas yang berlangsung selama dua siklus ini dapat disimpulkan bahwa pembelajaran tematik tema indahnya kebersamaan subtema keberagaman budaya bangsaku pembelajaran 4 dan 5 dengan menggunakan model pembelajaran Problem Based Learning untuk meningkatkan sikap kerja sama dan hasil belajar siswa di kelas IV SDN Kencana Indah 2 Kecamatan Rancaekek Kabupaten Bandung maka berdasarkan hasil penelitian diperoleh kesimpulan sebagai berikut :
1. Sikap kerja sama dan hasil belajar siswa sebelum menggunakan model Problem Based Learning pada pembelajaran tematik tema indahnya kebersaman subtema keberagaman budaya bangsaku di kelas IV SDN Kencana Indah 2 masih rendah dan tidak mencapai kriteria ketuntasan belajar klasikal. Hal ini dibuktikan pada siklus I jumlah siswa 33 orang yang mengalami ketuntasan belajar sebanyak 15 orang atau 45,5\%. Pada siklus II jumlah siswa 33 orang dalam uji awal prestasi belajar (pretest) yang mengalami ketuntasan belajar sebanyak 20 orang atau $60,6 \%$.

2. Respon siswa ketika pembelajaran menggunakan model Problem Based Learning dalam meningkatkan sikap kerja sama dan hasil belajar siswa di kelas IV SDN Kencana Indah 2 dapat diketahui dari data hasil angket. Pada siklus I persentase jawaban siswa yang memilih "ya" sebanyak 74,5\%, sedangkan pada siklus II diperoleh persentase jawaban siswa yang memilih "ya" sebanyak 91,5\% . Berdasarkan data tersebut diketahui bahwa respon siswa ketika pembelajaran menggunakan model Problem Based Learning yaitu mereka sangat menyukai pembelajaran tersebut.

3. Aktivitas belajar siswa ketika menggunakan model Problem Based Learning dalam meningkatkan sikap kerja sama dan hasil belajar siswa di kelas IV SDN Kencana Indah 2 dapat diketahui dari data siklus I sebanyak 15,2\%. Pada siklus II memperoleh sebanyak 93,9\%. Berdasarkan data tersebut, peningkatan hasil observasi pada 


\section{Didaktik : J urnal Pendidikan Guru Sekolah Dasar, ISSN : 2477-5673 \\ Sekolah Tinggi Keguruan dan IImu Pendidikan Subang \\ Volume I Nomor 2, J uli 2016}

aktivitas siswa dalam
pembelajaran menggunakan
Problem Based Learning
membuat siswa menjadi aktif,
kreatif dan mampu berkolaborasi
atau bekerja sama dengan teman-
temannya, sehingga akan saling
membantu dalam memecahkan
suatu permasalahan.

4. Proses

pembelajaran

pelaksanaan dengan menggunakan model Problem Based Learning dalam meningkatkan sikap kerja sama dan hasil belajar siswa di kelas IV SDN Kencana Indah 2 mencakup aktivitas pelaksanaan guru sudah terlaksana dengan sangat baik. Guru sudah mengelola kelas sesuai dengan langkah-langkah Problem Based Learning dengan baik. Hal ini dibuktikan pada hasil observasi oleh observer pada saat guru mengajar yaitu pada siklus I diperoleh nilai 3,37 dengan kategori penilaiannya adalah baik (B). Pada siklus II diperoleh nilai 3,73 dengan kategori penilaian sangat baik $(A)$.

5. Penggunaan model Problem Based Learning dapat meningkatkan sikap kerja sama dan hasil belajar siswa di kelas IV SDN Kencana Indah 2. Hasil belajar pada setiap siklus membuktikan adanya peningkatan, yaitu hasil tes siklus I dengan nilai rata-rata 61,2 dan ketuntasan 45,5\%, siklus II mencapai nilai rata-rata 74,2 dan ketuntasan $84,8 \%$.

Dari gambaran di atas dapat ditarik kesimpulan bahwa pembelajaran dengan menerapkan model Problem Based Learning dapat meningkatkan sikap kerja sama dan hasil belajar siswa kelas IV SDN Kencana Indah 2 Kecamatan Rancaekek Kabupaten Bandung dalam pembelajaran tematik tema indahnya kebersamaan subtema keberagaman budaya bangsaku.

\section{DAFTAR PUSTAKA}

Kementerian Pendidikan dan Kebudayaan. 2013 .Kurikulum 2013. Jakarta : Kementerian Pendidikan dan Kebudayaan.

Nina, Euis. 2009. Penerapan Model Contextual Teaching and Learning untuk Meningkatkan Hasil Belajar Siswa pada Konsep Tumbuhan. Bandung : Skripsi FKIP UNPAS. Tidak diterbitkan.

Purwanto, M. Ngalim. 2009. PrinsipPrinsip dan Teknik Evaluasi Pengajaran. Bandung : PT Remaja Rosdakarya.

Rusman. 2011. Model-model Pembelajaran Mengembangkan Profesionalisme Guru. Jakarta : PT. Raja Grafindo Persada.

Rusmono. 2012. Strategi Pembelajaran dengan Problem Based Learning itu Perlu. Jakarta : Ghalia Indonesia.

Sukardi. 2011. Evaluasi Pendidikan: Prinsip \& Operasionalnya. Jakarta : Bumi Aksara.

Suyitno, Teguh. 2013. Diakses dari halaman web tanggal 24 Mei 2014 dari:

http://bdksemarang.kemenag.go.id/?p =page\&id=272\#sthash.fdjzkT5p.dpuf

Trianto. 2013.

Desain

Pengembangan Pembelajaran Tematik bagi Anak Usia Dini TK/RA dan Anak Usia Awal SD/MI. Jakarta : Kencana Prenada Media Group.

Winataputra, Udin s, dkk. 2010. Materi dan Pembelajaran IPS SD. Jakarta : Erlangga 